\title{
Optimization of the Active Layer P3HT:PCBM for Organic Solar Cell
}

\author{
Mohamed Shaban ${ }^{1}$, Mohamed Benghanem ${ }^{1, * \mathbb{D}}$, Abdullah Almohammedi ${ }^{1}$ and Mohamed Rabia ${ }^{2,3}$ \\ 1 Physics Department, Faculty of Science, Islamic University of Madinah, P.O. Box 170, \\ Madinah 42351, Saudi Arabia; mssfadel@yahoo.com (M.S.); ard.almohammedi@hotmail.com (A.A.) \\ 2 Nanophotonics and Applications Laboratory, Physics Department, Faculty of Science, Beni-Suef University, \\ Beni-Suef 62514, Egypt; mohamedchem@science.bsu.edu.eg \\ 3 Polymer Research Laboratory, Chemistry Department, Faculty of Science, Beni-Suef University, \\ Beni-Suef 62514, Egypt \\ * Correspondence: benghanem_mohamed@yahoo.fr; Tel.: +966-507-346-783
}

Citation: Shaban, M.; Benghanem, M.; Almohammedi, A.; Rabia, M. Optimization of the Active Layer P3HT:PCBM for Organic Solar Cell. Coatings 2021, 11, 863. https:// doi.org/10.3390/coatings 11070863

Academic Editor: Chen Tei-Chen

Received: 25 June 2021

Accepted: 15 July 2021

Published: 19 July 2021

Publisher's Note: MDPI stays neutral with regard to jurisdictional claims in published maps and institutional affiliations.

Copyright: () 2021 by the authors. Licensee MDPI, Basel, Switzerland. This article is an open access article distributed under the terms and conditions of the Creative Commons Attribution (CC BY) license (https:// creativecommons.org/licenses/by/ $4.0 /)$.

\begin{abstract}
ITO/PEDOT:PSS/P3HT:PC ${ }_{60} \mathrm{BM} / \mathrm{Mg}$-Al organic solar cells (OSCs) were fabricated depending on optimization of Poly(3-hexylthiophene-2,5-diyl) (P3HT) and phenyl-C61-Butyric-Acid-Methyl Ester $\left(\mathrm{PC}_{60} \mathrm{BM}\right)$. The optimization of the active layer, $\mathrm{P} 3 \mathrm{HT}: \mathrm{PC}_{60} \mathrm{BM}$, was carried out under different spin frequencies coating from 900 to $3000 \mathrm{rpm}$. The post-production annealing temperature of all prepared OSC was studied from 130 to $190^{\circ} \mathrm{C}$. The holes transport layer, poly(3,4-ethylene dioxythiophene) polystyrene sulfonate (PEDOT:PSS), was prepared under constant conditions of $3000 \mathrm{rpm}$ for $35 \mathrm{~s}$, and annealing temperature $178^{\circ} \mathrm{C}$ for $15 \mathrm{~min}$. From our study, the optimum conditions for P3HT:PC ${ }_{60} \mathrm{BM}$ were spin coating of $3000 \mathrm{rpm}$, and annealing temperature of $160{ }^{\circ} \mathrm{C}$ for $5 \mathrm{~min}$. The optimum J-V parameters values for the prepared OSC were $J_{S C}=12.01 \mathrm{~mA} / \mathrm{cm}^{2}, V_{O C}=660 \mathrm{mV}$, $F F=59 \%, P C E=4.65 \%$, and $E Q E=61 \%$. A complete OSC with acceptable efficiency was designed using simple and low-cost techniques that may be utilized in the industry. Furthermore, the cost of the synthesized solar cell is projected to be around $1 \$ / \mathrm{cm}^{2}$, with the goal of lowering the cost and increasing efficiency in the future by incorporating more commercial nanostructured electron/hole transport components.
\end{abstract}

Keywords: organic solar cells polymers; annealing temperature; external quantum efficiency; parasitic resistances

\section{Introduction}

The organic solar cell (OSC) is a new generation of photovoltaic devices. Due to its simpler and cheaper production methods, OSC has a smart future. Researchers are doing their best to maximize the OSC's properties and to surpass the limits of low power conversion efficiency $(P C E)$ and fill factor $(F F)$. For increasing the efficiency of the prepared OSC, the photon to electron conversion process must be optimized. This was carried out by using new materials with high activity, good band-gap, and good recombination processes of the charge carrier [1-5]. Researchers are doing their best to reach the optimum values for open-circuit voltage $\left(V_{O C}\right)$ and short-circuit current density $\left(J_{S C}\right)[6,7]$. Active layer morphology, material structures, concentrations, and annealing temperature are the general parameters relevant to $V_{O C}$ and $J_{S C}$.

The annealing temperature is an important parameter for the enhancement of the PCE of the prepared organic solar cell. Through the annealing process, the morphology of the active layer is reshaped. This process affects the activity of the active layer, and in general, affects all the OSC. Recent work was presented about the impact of blend compositions and annealing temperatures on the optical characteristics of P3HT:PCBM-based OSC [8]. There were some other studies carried out to improve the PCE through the post-production annealing process for the prepared OSC $[9,10]$. Padinger et al. [11] obtained a PCE of 
3.5\% for ITO/PEDOT:PSS/P3HT:PCBM/LiF/Al OSC at a post-production annealing temperature of $75{ }^{\circ} \mathrm{C}$ for $4 \mathrm{~min}$. Reyes et al. [12] optimized the annealing temperature and time. The maximum $J_{S C}$ was $11.1 \mathrm{~mA} / \mathrm{cm}^{2}$ at $150{ }^{\circ} \mathrm{C}$ for $5 \mathrm{~min}$ due to the improvement in the film crystallinity. Li et al. [13] reported a better improvement in PCE of OSC after post-production annealing due to the improvement of the morphology and the working of the cathode as a barrier. The polymer and the cathode were smoother in contact, resulting in a better set of charges.

In addition, the enhancement in the morphology of the active layer due to annealing optimization causes more enhancements in the optical properties of the active layers. Erb et al. [14] studied the relationship between optical properties and crystallinity of P3HT:PCBM. The isolated PCBM molecules were dispersed into larger aggregates after annealing, while $\mathrm{P} 3 \mathrm{HT}$ aggregates were transformed into P3HT crystallites in these PCBM-free regions at the same time. The PCE enhancement of the annealed P3HT:PCBM OSC was due to the PCBM cluster's improved electron transportation and increased P3HT absorption.

Moreover, few studies tried to enhance the $P C E$ of OSCs through annealing the active layers only. Chen et al. [10] obtained PCE of 3.70\% for ITO/PEDOT:PSS/P3HT:PCBM/Al OSC by annealing the active layer for $5 \mathrm{~min}$ at $150{ }^{\circ} \mathrm{C}$.

In addition, the organic layers are influenced by environmental conditions such as temperature, oxygen, moisture content, and light exposure [15-20]. Lin et al. [21] stated that the low-temperature drying of the P3HT:PCBM active layer of OSCs improved their thermal stability and PCE. Matthew et al. [22] studied P3HT and its blend and confirmed that the OSC was stable up to $1000 \mathrm{~h}$ when irradiated in an inert atmosphere, but when irradiated in the atmospheric environment, the stability decreased to $700 \mathrm{~h}$. Maceu et al. [23] concluded that P3HTT aging was responsible for the oxidation of the alkyl side chain and the sulfur atom in the thiophene ring.

The superior features and optimum blend of $\mathrm{P} 3 \mathrm{HT}$ and $\mathrm{PCBM}$ promote dense research on OSCs based on P3HT:PCBM [24].

The PCE of the prepared solar cell depends on the composite ratio of P3HT:PCBM. Padinger et al. [25] and Schilinsky et al. [26] analyzed the P3HT:PCBM composition ratios of $1: 2$ and $1: 3$ and concluded that the PCE values were $2.8 \%$ and $3.5 \%$, respectively. At the 1:1 ratio composition, Huang et al. [27] studied the balanced electron and hole mobilities, and they figured that this gives a more orderly blend structure. Li et al. [28] used the 1,2-dichlorobenzene (oDCB) solvent for P3HT:PCBM and achieved 4.4\% PCE. They varied the solvent evaporation periods to control the growth rate and hence reported the $P C E$ values. They decided that slow-grown layers perform better than fast-grown layers. Supriyanto et al. prepared P3HT:PCBM variation of mass ratio but the PCE efficiency was not increased over $0.01 \%$ [29]. Chi et al. prepared P3HT:PCBM with an additional PCBM layer between the active layer and the cathode, in which the efficiency reached $4.24 \%$ [30]. Chang et al. fabricated P3HT:PCBM incorporated with silicon nanoparticles as a photoactive layer in more efficient organic photovoltaic devices, but he reached a maximum efficiency of 3.38\% [31]. Khairulaman et al. improved the performance of inverted type organic solar cells using copper iodide-doped P3HT:PCBM as the active layer, but the maximum PCE was $2.4 \%$ [32].

The PEDOT:PSS is applied as a hole transport layer (HTL) in the prepared OSCs. It possesses a $5 \mathrm{eV}$ working function and triggers the barrier of holes injection. In addition to that, PEDOT:PSS plenaries the rough ITO surfaces and thus avoids all local short-circuiting. Moreover, its high transmission and conductance are beneficial for the application of solar cells [33]. Therefore, it is important to design P3HT:PC ${ }_{60} \mathrm{BM}$-based OSC with PCE close to $5 \%$ through optimizing the fabrication parameters such as the spinning velocity and annealing temperature and testing different cathode metals.

In this study, ITO/PEDOT:PSS/P3HT:PC ${ }_{60} \mathrm{BM} / \mathrm{Mg}-\mathrm{Al}$ OSCs were fabricated by varying different parameters including post-production temperature of OSC, spin coating frequency of the active layer, and the use of $\mathrm{Al}$ or $\mathrm{Mg}-\mathrm{Al}$ as a cathode. The hole trans- 
port layer was PEDOT:PSS, which was prepared under the same conditions for all OSCs. P3HT:PC ${ }_{60} \mathrm{BM}$ concentration was $2 \mathrm{wt} . \%$, and the spin coating was varied from 900 to $3000 \mathrm{rpm}$. The post-production temperature was varied from 130 to $190^{\circ} \mathrm{C}$. The optimum $\mathrm{J}-\mathrm{V}$ parameters values for the prepared OSC were determined under different preparation conditions. Moreover, the key performance indicators are obtained and optimized.

\section{Experimental Part}

\subsection{Materials}

P3HT (698997-5G), PC 60 BM (Solenne b.v, Groningen, The Netherlands, 99.5\%), and ITO glasses were bought from Sigma Aldrich, Burlington, VT, USA. PEDOT:PSS (Clevios, Heraeus Epurio, Hanau, Germany), and Magnesium and Aluminium metals were purchased from VWR company, Ismaning, Germany.

\subsection{Solution Preparation}

The hole transport layer (PEDOT:PSS (Clevios, Heraeus Epurio, Hanau, Germany)) is used directly without any dilution, in which a filter of $0.45 \mu \mathrm{m}$ is used. The active and electron transport layer, $\mathrm{P} 3 \mathrm{HT}: \mathrm{PC}_{60} \mathrm{BM}$, is prepared 3:2 (1.8 wt.\%:1.2 wt.\%) in which $72 \mathrm{mg}$ P3HT and $48 \mathrm{mg}$ in $6 \mathrm{~mL}$ chlorobenzene are dissolved for 15 days in the glovebox using an additive solution of the peprazine (1 $\mathrm{wt} . \%)$.

\subsection{OSC Fabrication}

The OSC device preparation was carried out under different parameters; varying the spin coating for P3HT:PC ${ }_{60} \mathrm{BM}$ active layer (900 to $3000 \mathrm{rpm}$ ), post-production annealing temperature for all the prepaid solar cells, and changing the cathode metals.

ITO $(2.5 \mathrm{~cm} \times 2.5 \mathrm{~cm})$ was cleaned using water soap, toluene, acetone, and isopropanol, in which the cleaning was carried out using ultrasonic for $15 \mathrm{~min}$ for each solution. PEDOT:PSS was coated on ITO using spin coater working at $3000 \mathrm{rpm}$ for $15 \mathrm{~s}$, then annealed at $178{ }^{\circ} \mathrm{C}$ for $15 \mathrm{~min}$ in the air environment. After the annealing process, the ITO/PEDOT:PSS was transferred directly inside the glove box for drying. P3HT:PC 60 BM solutions were deposited on PEDOT:PSS at a spinning velocity varied from 900 to $3000 \mathrm{rpm}$. The thickness of P3HT:PC 60 BM was $\sim 290 \mathrm{~nm}$ at $900 \mathrm{rpm}$ and reduced to $\sim 160 \mathrm{~nm}$ at $3000 \mathrm{rpm}$, in a good approximation with the reciprocal square root of the spin speed. Finally, the cathode metals ( $\mathrm{Al}$ or $\mathrm{Mg}-\mathrm{Al}$ ) coated the previous layers. The evaporation of the metals was carried out using the physical evaporation process at $2.8 \times 10^{-6}$ bar with a total thickness of $463 \mathrm{~nm}$. The post-annealing process was studied on the prepared OSC. The annealing temperatures from 130 to $190{ }^{\circ} \mathrm{C}$ were carried out on the prepared OSC for 5 min inside the glove box.

\subsection{OSC Characterization and Experimental Measurements}

The analyses were carried out for the prepared active layers, P3HT:PC ${ }_{60} \mathrm{BM}$, and all the OSCs. For the produced P3HT:PC ${ }_{60} \mathrm{BM}$ active layer, optical spectra of absorbance, transmittance, and reflectance were measured using SPEC ORD ANALYTIC JENA AG spectrophotometer. The wavelength ranged from 300 to $1100 \mathrm{~nm}$. The optical spectra were measured at room temperature. The electrical analyses were carried out for all prepared OSCs; J-V in light (under solar simulator, Model CT100AAA, PET Inc., Moorpark, CA, USA) and dark (Computer-controlled source, Keithley 2400 AM1.5 illumination, (Keithley, Solon, OH, USA) Solar Light, XPS 400, (Solar Light Inc., Glenside, PA, USA) [33]. The average data points, $F F, R_{P}, R_{S}, J_{S C}, V_{O C}$, and $P C E$, were gathered from four-time repetitions using four solar cells prepared under identical conditions to obtain more precise measurements and findings. This means that we constructed four solar cells under identical conditions and averaged the results; this technique of research yields more precise measurements and outcomes. 
EQE measurements were recorded under the illumination of a monochromatized halogen lamp. The incident light beam was chopped with a mechanical chopper and the photocurrent was detected using a lock-in-amplifier.

\section{Results and Discussion}

The optical behaviors of the prepared active layer, $\mathrm{P} 3 \mathrm{HT}: \mathrm{PC}_{60} \mathrm{BM}$, were studied under different annealing temperature for the prepared ITO/PEDOT:PSS/P3HT:PC ${ }_{60} \mathrm{BM} / \mathrm{Al}$ OSC. The concentration of the P3HT:PC ${ }_{60} \mathrm{BM}$ solution was $2 \mathrm{wt} . \%$ and the spin coating was carried out at $1500 \mathrm{rpm}$ for $60 \mathrm{~s}$. Figure 1a represents the reflectance and transmittance spectra for the active layer, while Figure $1 \mathrm{~b}$ shows the absorbance spectra. The main absorption features are observed in Figure $1 \mathrm{~b}$. The absorption shoulder around $\sim 332 \mathrm{~nm}$ is associated with PCBM, but the main peak at higher wavelengths is associated with P3HT absorption. The peak at $\sim 487 \mathrm{~nm}$ is ascribed to band-to-band transitions inferred from $\pi-\pi^{*}$ transitions between the allowed highest occupied molecular orbital (HOMO) and the lowest unoccupied molecular orbital (LUMO) of P3HT:PC ${ }_{60} \mathrm{BM}$. At high annealing temperature $\left(>160^{\circ} \mathrm{C}\right)$, this peak displayed a small blue shift, which might be attributed to the interruption of the structure and the orientation for the P3HT chain ordering due to the heat treatment. Absorption features (S0, S1, S2) corresponding to P3HT excitonic absorption with the participation of Frenkel excitons were found at $\sim 602,550$, and $510 \mathrm{~nm}$, respectively. These excitonic absorptions correspond to the formation of a singlet exciton, one exciton, and one phonon, and one exciton plus two phonons, respectively. The absorption at $602 \mathrm{~nm}$ refers to P3HT inter-chain stacking, signifying an improvement in chain ordering whilst the absorption at $550 \mathrm{~nm}$ is allocated to the extended conjugated polymer. From Figure 1a,b, the active layer works well in the UV and Vis light region, especially from 300 to $650 \mathrm{~nm}$. At $140{ }^{\circ} \mathrm{C}$, the transmission is maximum in the IR region and minimum in the UV/Vis region. In other words, a reversal behavior is observed between IR and UV/Vis regions under the effect of the annealing temperature. Besides the absorption band in the UV region, a strong and wide absorption band extending over the visible light region is observed. The active layer homogeneity appears in the absorbance, transmittance, and reflectance spectra and is related to the annealing temperature from 140 to $160{ }^{\circ} \mathrm{C}$. Figure 1 shows nearly perfect transmission spectra with no evidence of active layer or thickness inhomogeneity or scattering. Furthermore, because it is practically difficult to measure these spectra at the same spot on the film multiple times, and as we carry out and produce the same spectra, the films must have good homogeneity in composition or thickness.

The effect of spinning frequency on the optical properties of the deposited P3HT:PC ${ }_{60} \mathrm{BM}$ was studied, as shown in Figure 2a,b. The spinning frequency was varied from 900 to $3000 \mathrm{rpm}$. The P3HT:PC 60 BM solution concentration was $2 \mathrm{wt} . \%$, and the annealing temperature was $160{ }^{\circ} \mathrm{C}$ for $5 \mathrm{~min}$. The transmission of the active layer is affected by the spinning frequency. In the IR region, the transmission is decreased visibly by increasing the spinning velocity, but in the UV/Vis region, a reversal behavior is observed. From Figure 2a,b, the optical properties confirm the strong absorption of the active layers in the UV and Vis range, especially from 300 to $650 \mathrm{~nm}$. As the spinning velocity decreased, the optical absorption improved, which was related to the thickness effect of the active layer. Two absorption peaks are observed around 350 and $500 \mathrm{~nm}$. The photoluminescence study of the prepared P3HT:PC ${ }_{60} \mathrm{BM}$ is mentioned in Figure S1a,b (Supplementary Materials). From this figure, the optimum values for the PL study are observed for the films that were annealed at $160{ }^{\circ} \mathrm{C}$ for $5 \mathrm{~min}$ and deposited at $3000 \mathrm{rpm}$, which confirm the optimized values through the optical properties study. 

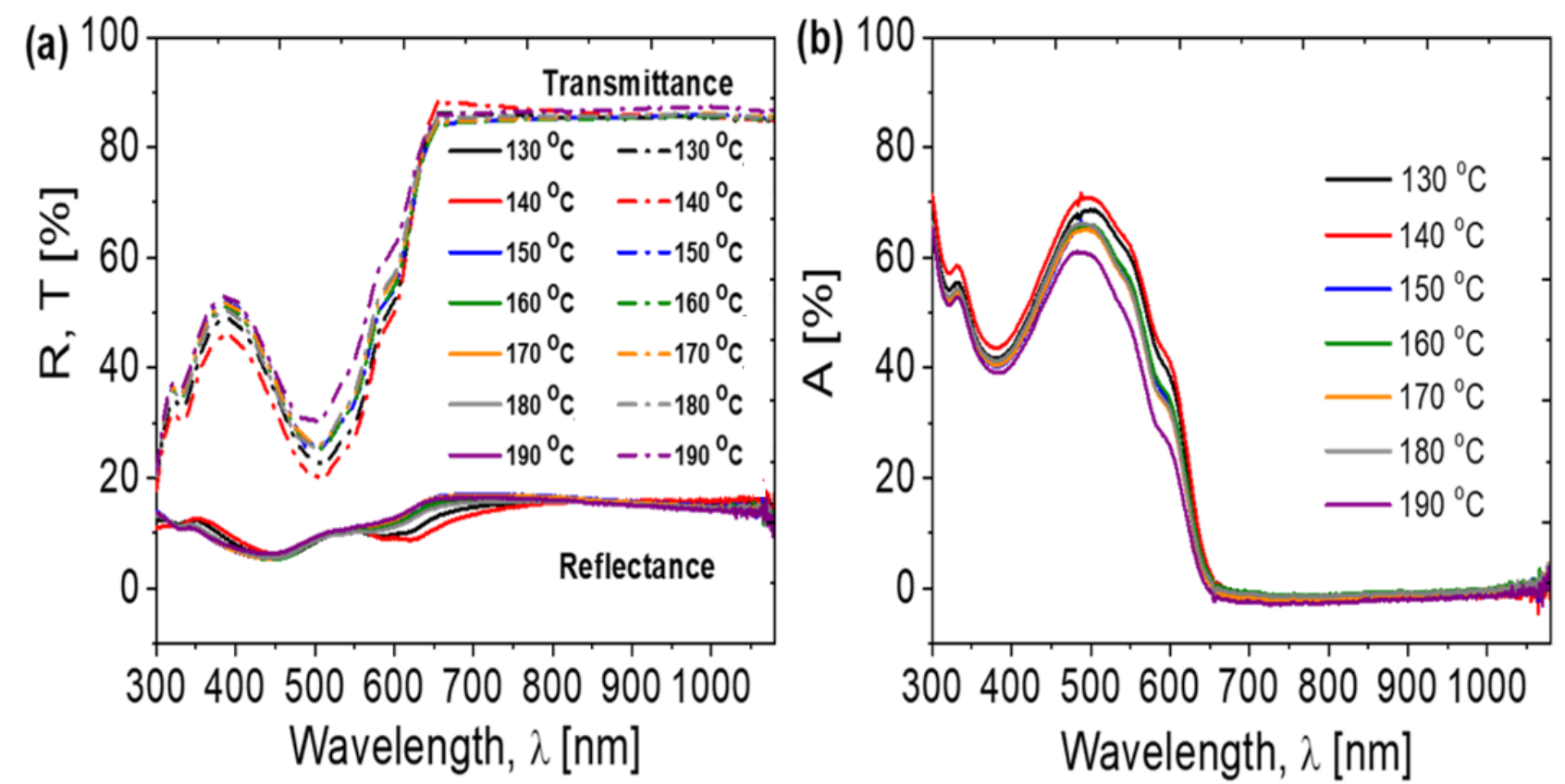

Figure 1. (a) Reflectance and transmittance and (b) absorbance spectra for $\mathrm{P} 3 \mathrm{HT}: \mathrm{PC}_{60} \mathrm{BM}$, which were prepared at $1500 \mathrm{rpm}$ for $60 \mathrm{~s}$ and annealed at different temperatures.
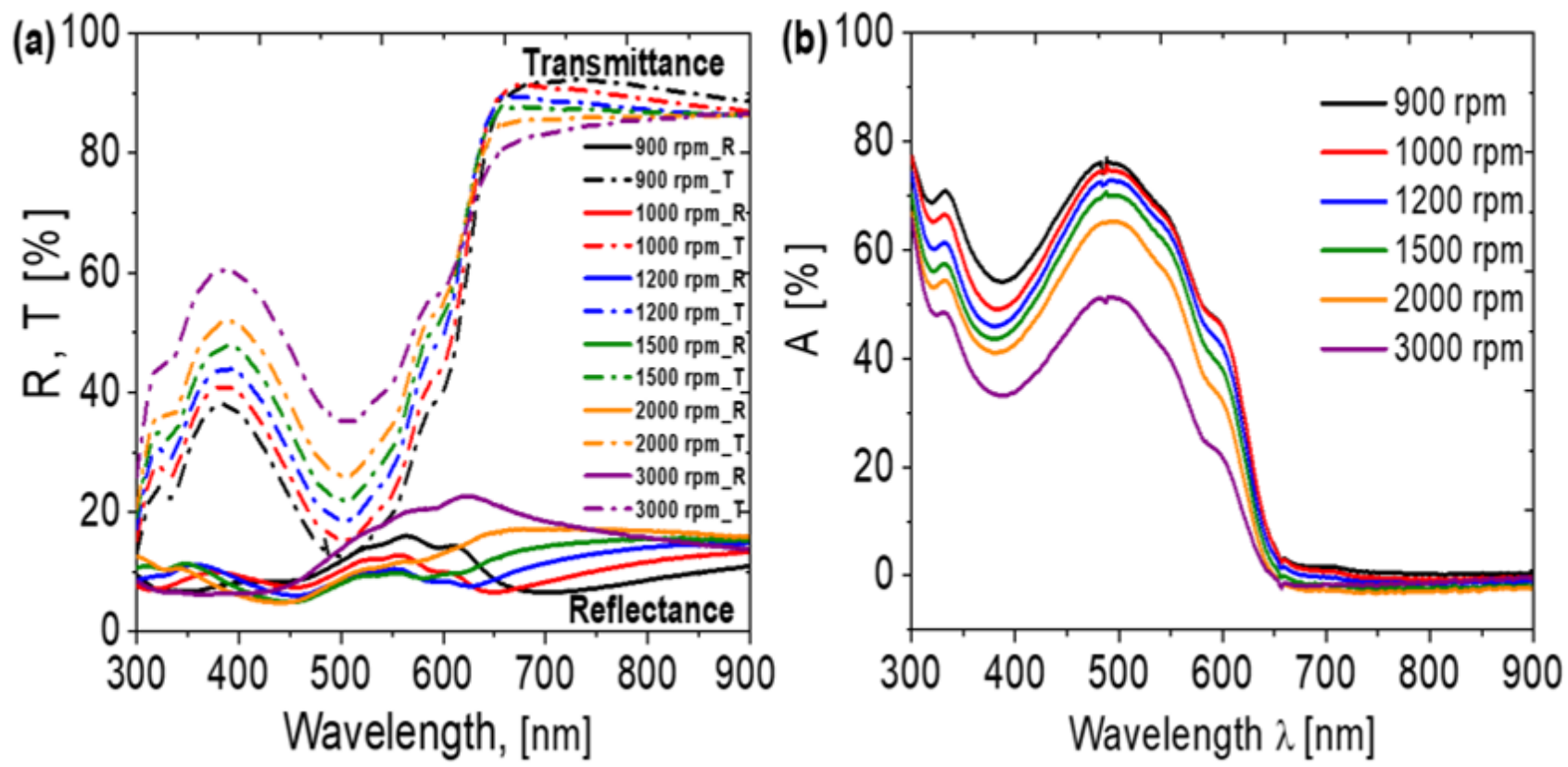

Figure 2. (a) Reflectance and transmittance, and (b) absorbance spectra for the active layers, $\mathrm{P} 3 \mathrm{HT}: \mathrm{PC}{ }_{60} \mathrm{BM}$, which were prepared at different spin frequencies and annealed at $160^{\circ} \mathrm{C}$ for $5 \mathrm{~min}$.

The effect of post-production temperature from 130 to $190^{\circ} \mathrm{C}$ on the J-V characteristics of the prepared OSCs under solar simulator and in the dark conditions are shown in Figure 3. The photovoltaic parameters $\left(P C E \%, F F \%, V_{O C}\right.$, and $\left.J_{S C}\right)$, the parallel and series resistances $\left(R_{P}, R_{S}\right)$ are estimated from the J-V characteristics in Figure 3 and presented in Figure $4 \mathrm{a}-\mathrm{f}$ as a function of the annealing temperature. The values of the different parameters are reported in Table 1 . The $160^{\circ} \mathrm{C}$ annealing temperature has the optimum effect on the photovoltaic parameters of the prepared OSC, whereas the values of $F F \%$ and $P C E \%$ are $53 \%$ and $3.68 \%$. Then, their values are decreased to $40 \%$ and $2.21 \%$ as the 
temperature increased to $190{ }^{\circ} \mathrm{C}$. The integral values for the I-V study under light are presented in Figure S2a.
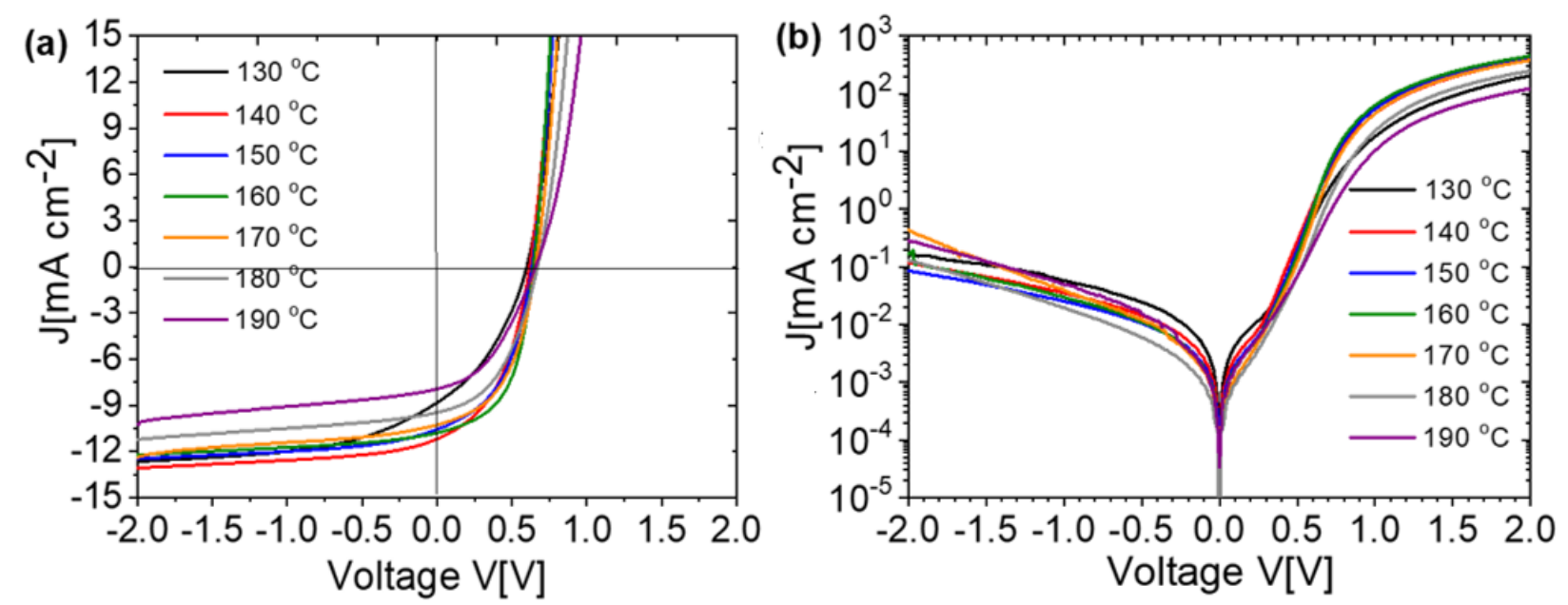

Figure 3. J-V curves under (a) the solar simulator and (b) in dark for the prepared OSC with the active layer prepared at different temperatures.

Table 1. Summary of the obtained photovoltaic parameters from the J-V data for OSCs with Al cathode, whereas the active layer was prepared at different annealing temperatures.

\begin{tabular}{ccccccccccc}
\hline $\begin{array}{c}\text { Annealing } \\
\text { Temperature }\left({ }^{\circ} \mathbf{C}\right)\end{array}$ & $\begin{array}{c}J_{S C} \\
\left(\mathbf{m A} / \mathbf{c m}^{2}\right)\end{array}$ & $V_{O C}(\mathbf{m V})$ & $\boldsymbol{F F} \mathbf{( \% )}$ & $\boldsymbol{P C E} \mathbf{( \% )}$ & $\boldsymbol{R}_{S}(\boldsymbol{\Omega})$ & $\boldsymbol{R}_{\boldsymbol{P}}(\boldsymbol{\Omega})$ & $\begin{array}{c}\text { Area } \\
\left(\mathbf{c m}^{2}\right)\end{array}$ & $\begin{array}{c}\boldsymbol{P}_{\max } \\
(\mathbf{m W})\end{array}$ & $\boldsymbol{V}_{\boldsymbol{m}}(\mathbf{m V})$ & $\begin{array}{c}J_{m} \\
\left(\mathbf{m A} / \mathbf{c m}^{2}\right)\end{array}$ \\
\hline 130 & 8.82 & 597 & 37 & 1.95 & 8 & 376 & 0.42 & 0.82 & 360 & 5.43 \\
140 & 11.17 & 616 & 45 & 3.09 & 6 & 579 & 0.42 & 1.3 & 400 & 7.74 \\
150 & 10.56 & 631 & 47 & 3.15 & 5 & 651 & 0.42 & 1.32 & 430 & 7.32 \\
$\mathbf{1 6 0}$ & $\mathbf{1 0 . 7 8}$ & $\mathbf{6 4 0}$ & $\mathbf{5 3}$ & $\mathbf{3 . 6 8}$ & $\mathbf{5}$ & $\mathbf{1 0 3 5}$ & $\mathbf{0 . 4 2}$ & $\mathbf{1 . 5 4}$ & 460 & $\mathbf{8}$ \\
170 & 10.26 & 655 & 49 & 3.29 & 6 & 897 & 0.42 & 1.38 & 450 & 7.32 \\
180 & 9.46 & 669 & 45 & 2.85 & 8 & 1055 & 0.42 & 1.2 & 420 & 6.79 \\
190 & 8.24 & 664 & 40 & 2.21 & 13 & 987 & 0.42 & 0.93 & 390 & 5.67 \\
\hline
\end{tabular}

Bold: Just to highlight the optimized OSC device at $160^{\circ} \mathrm{C}$.

The optimized OSC device at $160{ }^{\circ} \mathrm{C}$ illustrated $V_{O C}$ of $640 \mathrm{mV}$ and $J_{S C}$ of $10.783 \mathrm{~mA} / \mathrm{cm}^{2}$. The values of $J_{S C}$ are decreased after $160^{\circ} \mathrm{C}$, as shown in Figure $4 \mathrm{~d}$. The small change in $J_{S C}$ at about $160^{\circ} \mathrm{C}$ indicates that the increase in charge transportations is not accompanied by significant phase separation or breakdown in the active layer [34-36]. The increase in $J_{S C}$ values from 8.821 to $10.783 \mathrm{~mA} / \mathrm{cm}^{2}$ when increasing the annealing temperature from 130 to $160{ }^{\circ} \mathrm{C}$ refers to the improvement of the photon-to-current conversion efficiency $(E Q E)$. From the values of $V_{O C}$ and $J_{S C}$, the optimum power for the solar cell is obtained at $160{ }^{\circ} \mathrm{C}$ due to the multiply of the $V_{O C}$ and $J_{S C}$ values. Based on the obtained values of $P C E$, $F F, V_{O C}$, and $J_{S C}$; the optimum annealing temperature was $160^{\circ} \mathrm{C}$ for the preparation of the OSC.

On the other hand, the J-V characteristics in dark at different annealing temperatures are illustrated in Figure 3b. From these characteristics, the estimated parallel resistance $\left(R_{P}\right)$ increases by increasing the annealing temperature from 130 to $160^{\circ} \mathrm{C}$ and then decreases as shown in Figure 4e. This highest $R_{P}$ value is obtained at $160{ }^{\circ} \mathrm{C}$ and contributes to the improvement of the vertical phase alignment. This indeed improves the performances of the OSCs under lighting. At the same time, there is a decrease in the $R_{S}$ value until it reaches $5 \Omega$ at 150 and $160^{\circ} \mathrm{C}$, as shown in Figure $4 \mathrm{f}$. The decrease of $R_{S}$ results in enhanced charge transportation, which also validates the observed increase of the fill factor $(F F)$. In other words, the high $F F$ at $160^{\circ} \mathrm{C}$ of the optimized OSC resulted in a low $R_{S}$ of $5 \Omega$. This indicates the reduction of the potential barrier for holes' transportation at the interface. 

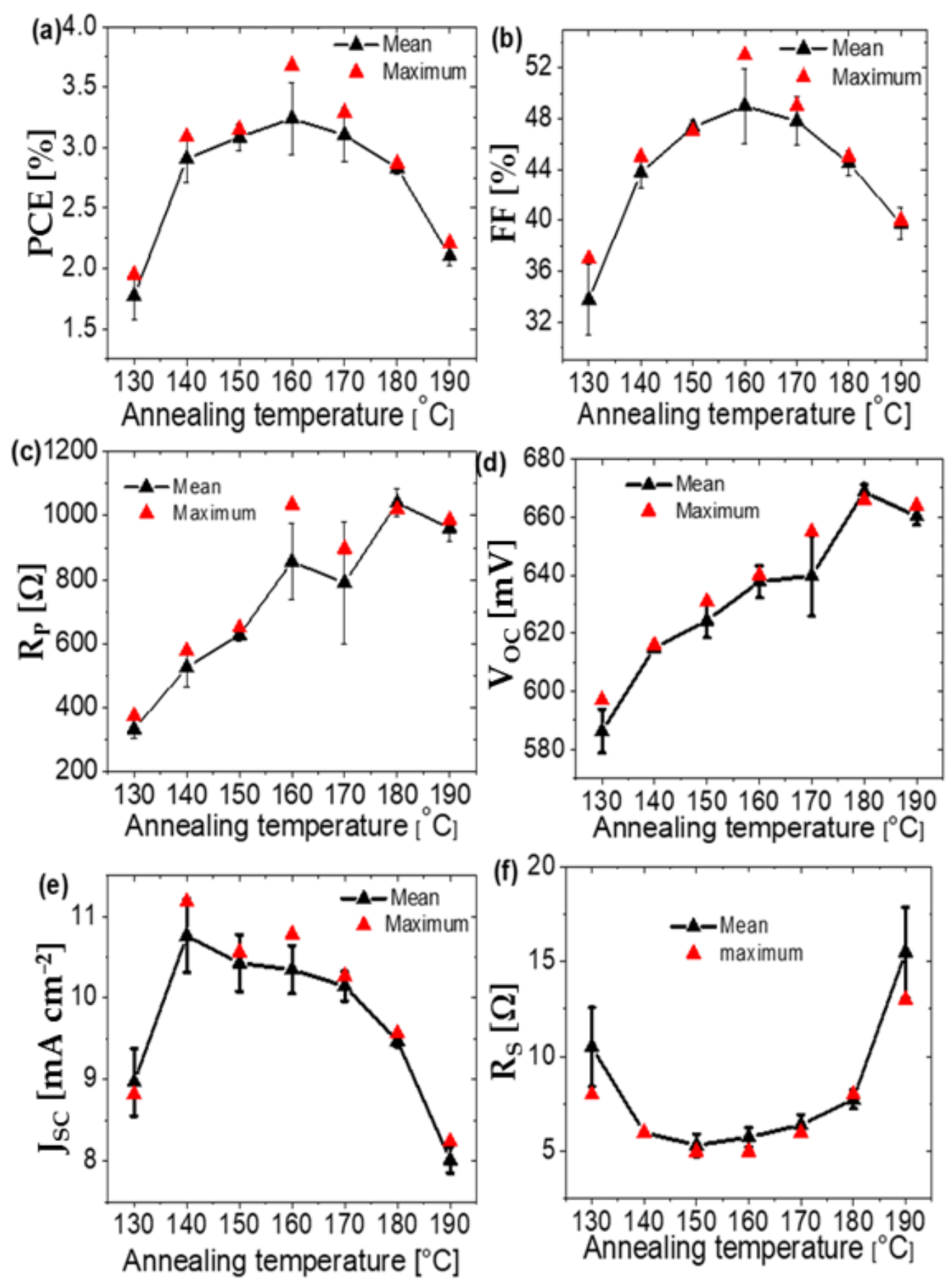

Figure 4. Variation of (a) PCE, (b) FF, (c) $V_{O C}$, (d) $J_{S C}$, (e) $R_{P}$, and (f) $R_{S}$ for OSCs with the active layer prepared at different temperatures from 130 to $190{ }^{\circ} \mathrm{C}$.

To study the effect of the active layer thickness, P3HT:PC ${ }_{60} \mathrm{BM}$, on the efficiency of the prepared solar cell, the spin coating frequency is changed from 900 to $3000 \mathrm{rpm}$ for this active layer coating. The concentration of the active layer solution is $2 \mathrm{wt} \%$, and the post-production annealing temperature is $160{ }^{\circ} \mathrm{C}$ for $5 \mathrm{~min}$. In addition to that, the hole transport layer, PEDOT:PSS, spin frequency coating is $3000 \mathrm{rpm}$ for $35 \mathrm{~s}$, and the annealing temperature for this layer is $178{ }^{\circ} \mathrm{C}$ for $15 \mathrm{~min}$. The study of different thicknesses was carried out on the prepared solar cell with $\mathrm{Al}$ and $\mathrm{Mg}$-Al metals as cathodes.

Figure 5a,b represents the J-V curves under different spin coating from 900 to $3000 \mathrm{rpm}$ for the active layer, P3HT:PC ${ }_{60} \mathrm{BM}$, under solar simulator and dark, respectively, using $\mathrm{Al}$ metal as a cathode. At the same time, Figure $5 c$, d represents J-V curves under different spin coating from 900 to $3000 \mathrm{rpm}$ for the active layer, $\mathrm{P} 3 \mathrm{HT}: \mathrm{PC}_{60} \mathrm{BM}$, under solar simulator and 
dark, respectively, using $\mathrm{Mg}$-Al metal as a cathode. Table 2 summarized all the parameters obtained from Figure $5 \mathrm{a}-\mathrm{d}$. In addition to that, the statistical calculations for the different parameters are mentioned in Figures $6 \mathrm{a}-\mathrm{f}$ and $7 \mathrm{a}-\mathrm{f}$. The high standard deviations may be due to the average data being taken from four-time repetition for four solar cells with the same preparation conditions. Moreover, the integral values for the I-V study under light are presented in Figure S2b,c (Supplementary Materials).

From Table 2 and the statistical calculations (Figure 6a,b), the optimum values of $P C E$ are $4.21 \%$ at $2000 \mathrm{rpm}$ and $4.65 \%$ at $3000 \mathrm{rpm}$ for $\mathrm{Al}$ cathode and $\mathrm{Mg}-\mathrm{Al}$ cathode, respectively. From Figure $5 \mathrm{a}$ and Table 2, the J-V characteristics under the solar simulator are affected by the spin coating frequency, 900 to $3000 \mathrm{rpm}$, of the deposited active layer. From Table 2, and the calculated statistical parameters in Figures 6 and 7, there is more enhancement in the parameters obtained using Al-cathode from J-V curves by increasing the spin coating frequency from 900 to $2000 \mathrm{rpm} ; V_{O C}=653 \mathrm{mV}, F F=54 \%$, and $P C E=4.21 \%$. The values of the optimum performance for the prepared OSCs are observed at $3000 \mathrm{rpm}$ using the $\mathrm{Mg}-\mathrm{Al}$ as a cathode; $J_{S C}=12.01 \mathrm{~mA} \cdot \mathrm{cm}^{-2}, V_{O C}=660 \mathrm{mV}, F F=59 \%$, and $P C E=4.65 \%$. This means that there are more enhancements in the OSC performance by using $\mathrm{Mg}$ metal in the construction of the cathode. This $\mathrm{Mg}$ metal adds more enhancements in the electron transport from the active layer to the cathode.

Thus, an explanation can be introduced based on a diode equivalent circuit model containing two additional resistors $R_{S}$ and $R_{P}$ connected in series and parallel, as shown in Figure S3 (Supplementary Materials). Shockley equations for $V_{O C}$ and $J_{S C}$, can be used to describe current density-voltage curves and solve the circuit model analytically resulting in fitting parameters such as $R_{S}, R_{P}$, reverse saturation current density $\left(J_{0}\right)$, and the ideality factor $(n)$ of a solar cell that is similar to a single diode $[37,38]$.

$$
\begin{aligned}
& V_{O C}=\frac{K T}{e} \ln \left[1+\frac{J_{p h}}{J_{o}}\left(\tilde{\tilde{1}}-\frac{V_{O C}}{J_{p h} R_{P} A}\right)\right] \simeq \frac{K T}{e} \ln \left[1-\frac{J_{p h}}{J_{o}}\right], \\
& J_{S C}=-\frac{1}{1+\frac{R_{S}}{R_{P}}}\left[J_{p h}-J_{o}\left[\exp \left(\frac{\left|J_{S C}\right| R_{S} A}{\frac{n k T}{e}}\right)-1\right] \simeq-J_{p h},\right.
\end{aligned}
$$

where $J_{p h}$ is the light-induced current density, $e$ is the elementary charge, $k$ is the Boltzmann constant $\left(8.617 \times 10^{-5} \mathrm{eV} \mathrm{K}^{-1}\right), T$ is the temperature, and $A$ is the area of the cell. According to the equations above, a higher $R_{P}$ will likely increase $V_{O C}$, whereas a higher $R_{S}$ will likely limit $J_{S C}$. Thus, large $R_{P}$ and small $R_{S}$ are desirable. Equations (1) and (2) show that when $R_{S}$ is small and $R_{P}$ is high enough, parasitic resistance has a greater impact on FF. FF can be expressed as a function of normalized $V_{O C}\left(V_{o c}=e V_{O C} / n k T\right)$, normalized $R_{S}\left(R_{S}=R_{S} / R_{C H}\right)$, and normalized $R_{P}\left(R_{P}=R_{P} / R_{C H}\right)$, where the characteristic resistance $\left(R_{C H}\right)$ is defined as $V_{O C} /\left(J_{S C} A\right)$, and $R_{C H}$ represents the output resistance of the OSC at the maximum power.

The J-V curves in dark for the different spin coating frequencies, 900 to $3000 \mathrm{rpm}$, are illustrated in Figure 5b,d for the prepared OSC with Al and Mg-Al cathode, respectively. In addition, the statistical calculations of $R_{P}$ and $R_{S}$ for the dark current are mentioned in Figure 7c-f. From Table 2 and Figure 7c,d, the $R_{P}$ has values of 2139 and $2041 \Omega$ (at $3000 \mathrm{rpm}$ ), for the prepared OSC with $\mathrm{Al}$ and $\mathrm{Mg}$-Al cathode, respectively. On the other hand, the $R_{S}$ values have values of 7 and $5 \Omega$ (at $3000 \mathrm{rpm}$ ), for $\mathrm{Al}$ and $\mathrm{Mg}-\mathrm{Al}$, respectively. For all electrochemical parameters calculated from J-V under the solar simulator or in dark, the $\mathrm{Mg}$ metal makes more enhancement in the electron transport in the prepared OSC for enhancing the efficiency. 

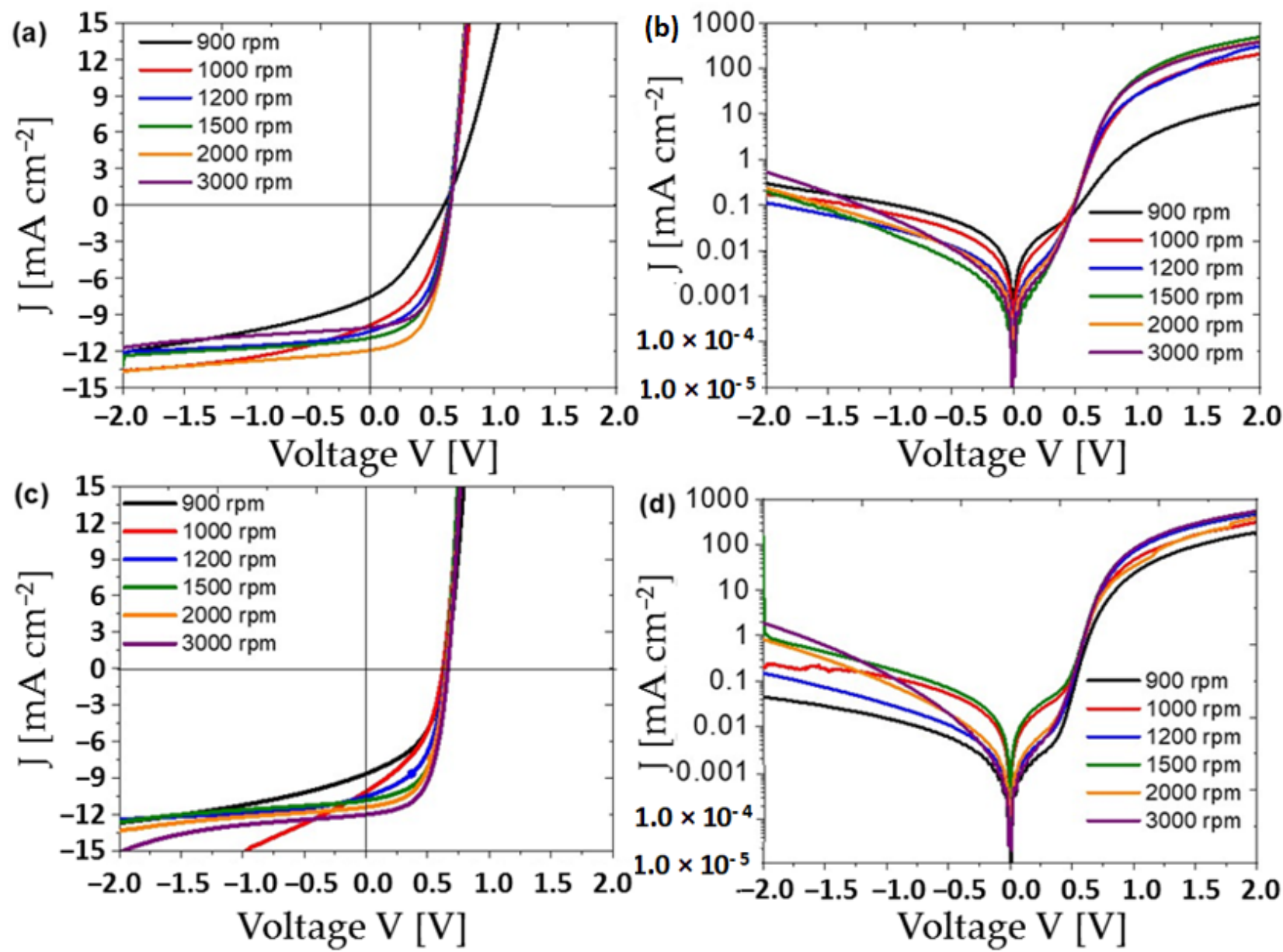

Figure 5. J-V curves under light (left column) and in dark (right column) for OSCs deposited at different spin coating frequencies from 900 to $3000 \mathrm{rpm}$ with (a,b) Al cathode and (c,d) Mg-Al cathode.

Table 2. Summary of the obtained photovoltaic parameters from the J-V data for OSCs with $\mathrm{Al}$ and $\mathrm{Mg}-\mathrm{Al}$ metal cathodes, whereas the active layer was prepared at different spin coating frequencies.

\begin{tabular}{|c|c|c|c|c|c|c|c|c|c|c|}
\hline $\begin{array}{c}\text { Spin Frequency } \\
\text { (rpm) }\end{array}$ & Cathode & $\begin{array}{c}J_{S C} \\
\left(\mathrm{~mA} / \mathrm{cm}^{2}\right)\end{array}$ & $\begin{array}{c}V_{O C} \\
(\mathrm{mV})\end{array}$ & $F F(\%)$ & $\begin{array}{l}P C E \\
(\%)\end{array}$ & $R_{S}(\Omega)$ & $R_{P}(\Omega)$ & $\begin{array}{l}P_{\max } \\
(\mathrm{mW})\end{array}$ & $\begin{array}{c}V_{m} \\
(\mathrm{mV})\end{array}$ & $\begin{array}{c}J_{m} \\
\left(\mathrm{~mA} / \mathrm{cm}^{2}\right)\end{array}$ \\
\hline 900 & $\mathrm{Mg}-\mathrm{Al}$ & 8.649 & 639 & 47 & 2.61 & 9 & 599 & 1.1 & 450 & 5.80 \\
\hline 1000 & $\mathrm{Mg}-\mathrm{Al}$ & 10.138 & 620 & 44 & 2.74 & 5 & 380 & 1.15 & 430 & 6.38 \\
\hline 1200 & Mg-Al & 10.524 & 642 & 52 & 3.49 & 5 & 754 & 1.47 & 460 & 7.59 \\
\hline 1500 & $\mathrm{Mg}-\mathrm{Al}$ & 10.844 & 646 & 58 & 4.09 & 4 & 1562 & 1.72 & 480 & 8.52 \\
\hline 2000 & $\mathrm{Mg}-\mathrm{Al}$ & 11.408 & 650 & 56 & 4.19 & 6 & 1755 & 1.76 & 470 & 8.91 \\
\hline 3000 & Mg-A1 & 12.01 & 660 & 59 & 4.65 & 5 & 2041 & 1.95 & 480 & 9.70 \\
\hline 900 & $\mathrm{Al}$ & 7.571 & 602 & 34 & 1.55 & 5.7 & 477 & 0.65 & 330 & 4.71 \\
\hline 1000 & $\mathrm{Al}$ & 9.872 & 636 & 44 & 2.78 & 8 & 536 & 1.17 & 410 & 6.79 \\
\hline 1200 & $\mathrm{Al}$ & 10.397 & 637 & 50 & 3.32 & 5 & 784 & 1.39 & 450 & 7.37 \\
\hline 1500 & $\mathrm{Al}$ & 10.929 & 644 & 52 & 3.67 & 6 & 1235 & 1.54 & 450 & 8.15 \\
\hline 2000 & $\mathrm{Al}$ & 11.944 & 653 & 54 & 4.21 & 6 & 1591 & 1.77 & 460 & 9.15 \\
\hline 3000 & $\mathrm{Al}$ & 10.08 & 653 & 56 & 3.71 & 7 & 2139 & 1.56 & 470 & 7.89 \\
\hline
\end{tabular}



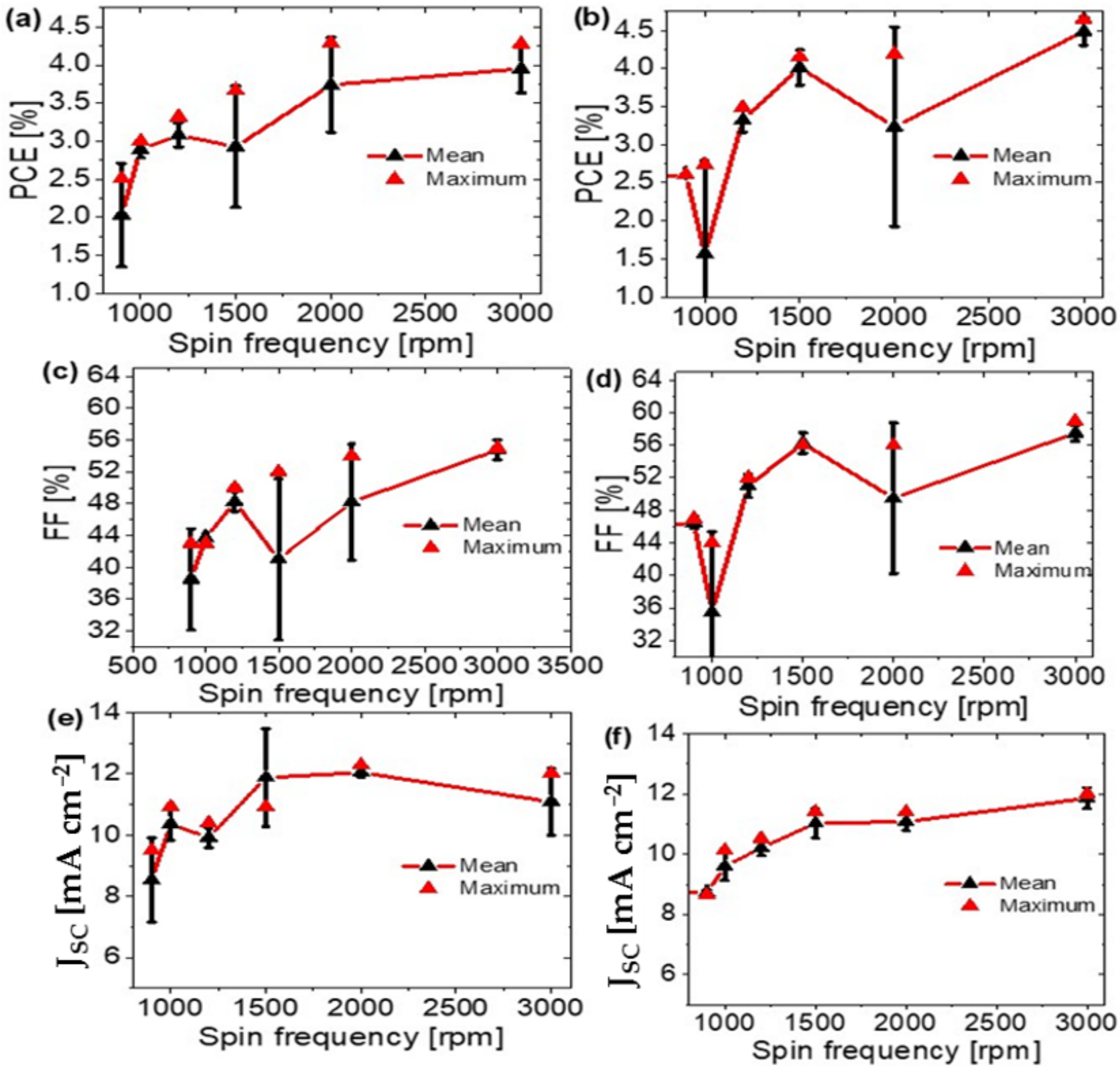

Figure 6. Statistical calculations of $P C E, F F$, and $J_{S C}$ for the prepared OSCs under different spin coating frequencies with $(\mathbf{a}, \mathbf{c}, \mathbf{e}) \mathrm{Al}$ and $(\mathbf{b}, \mathbf{d}, \mathbf{f}) \mathrm{Mg}-\mathrm{Al}$ cathode, respectively.

The external quantum efficiency $(E Q E)$ for the prepared OSC is determined under the effect of post-production annealing temperature, as shown in Figure 8. From this figure, high values of $E Q E$ are observed for the OSCs annealed at temperatures $\leq 160{ }^{\circ} \mathrm{C}$. The highest $E Q E$ value is observed at $130{ }^{\circ} \mathrm{C}$ in the UV region, whereas in the visible light region the highest value is observed at $140{ }^{\circ} \mathrm{C}$. Under the full UV-Vis region, $160{ }^{\circ} \mathrm{C}$ can be considered as the optimized annealing temperature for the designed OSCs. This is related to the response of the active layer to the incident photons and the generation of a high density of charge carriers.

To optimize the prepared organic solar cell, the EQE is determined at different thicknesses of the active layer and presented in Figure 9. From Figure 9a, the ITO/PEDOT:PSS/ P3HT:PC ${ }_{60} \mathrm{BM} / \mathrm{Al}$ OSC showed the highest EQE (59\%) at $3000 \mathrm{rpm}$. Using Mg-Al cathode instead of $\mathrm{Al}$ cathode, Figure $9 \mathrm{~b}$, the EQE reached a value of $61 \%$ for ITO/PEDOT:PSS/ P3HT:PC ${ }_{60} \mathrm{BM} / \mathrm{Mg}-\mathrm{Al}$ OSC. From the EQE values, the JSC values were calculated and presented in Figures S4-S6 (Supplementary Materials). 

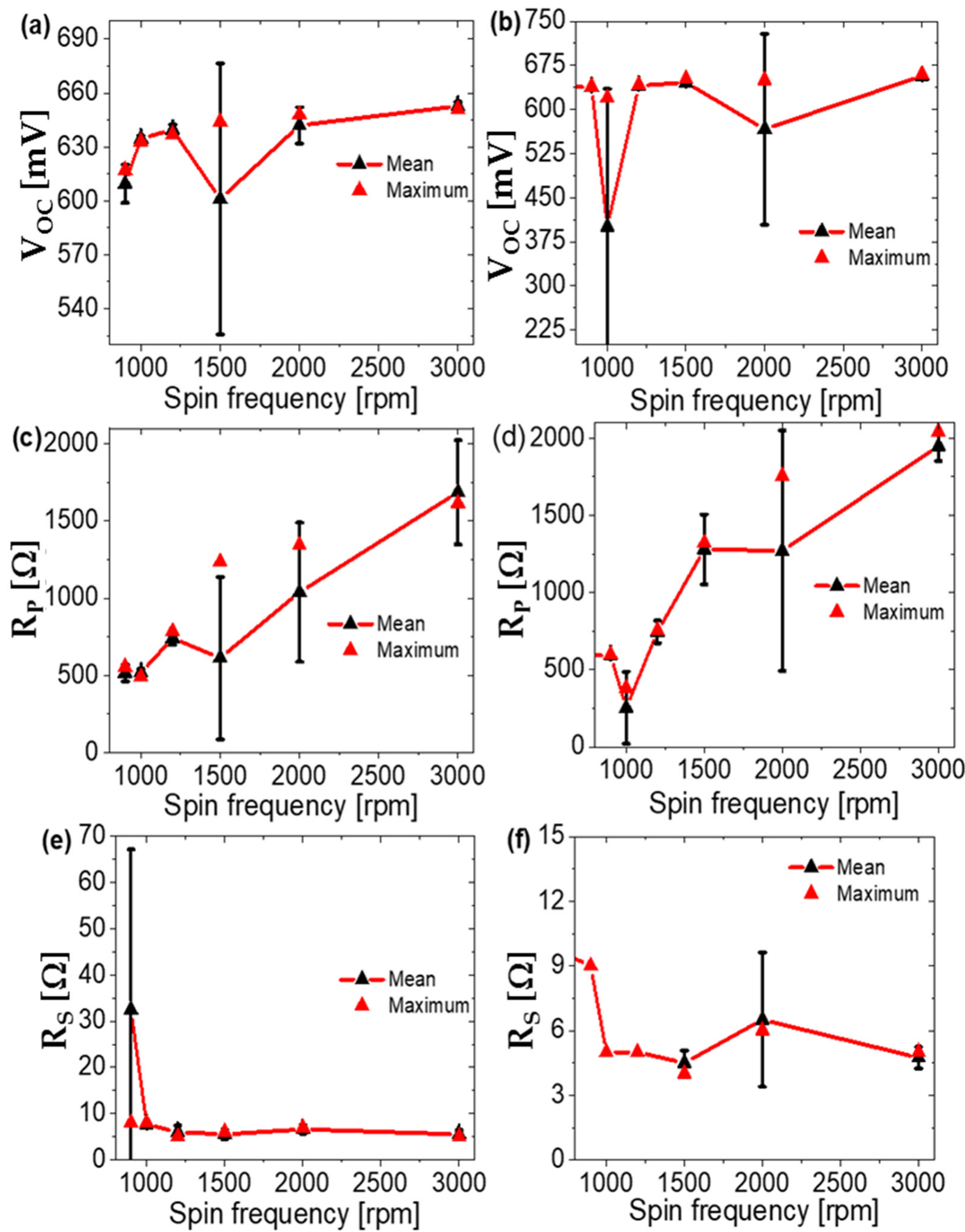

Figure 7. Statistical calculations of $V_{O C}, R_{P}$, and $R_{S}$ for the prepared OSCs under varied spin coating frequencies with $(\mathbf{a}, \mathbf{c}, \mathbf{e}) \mathrm{Al}$ and $(\mathbf{b}, \mathbf{d}, \mathbf{f}) \mathrm{Mg}-\mathrm{Al}$ cathode, respectively. 


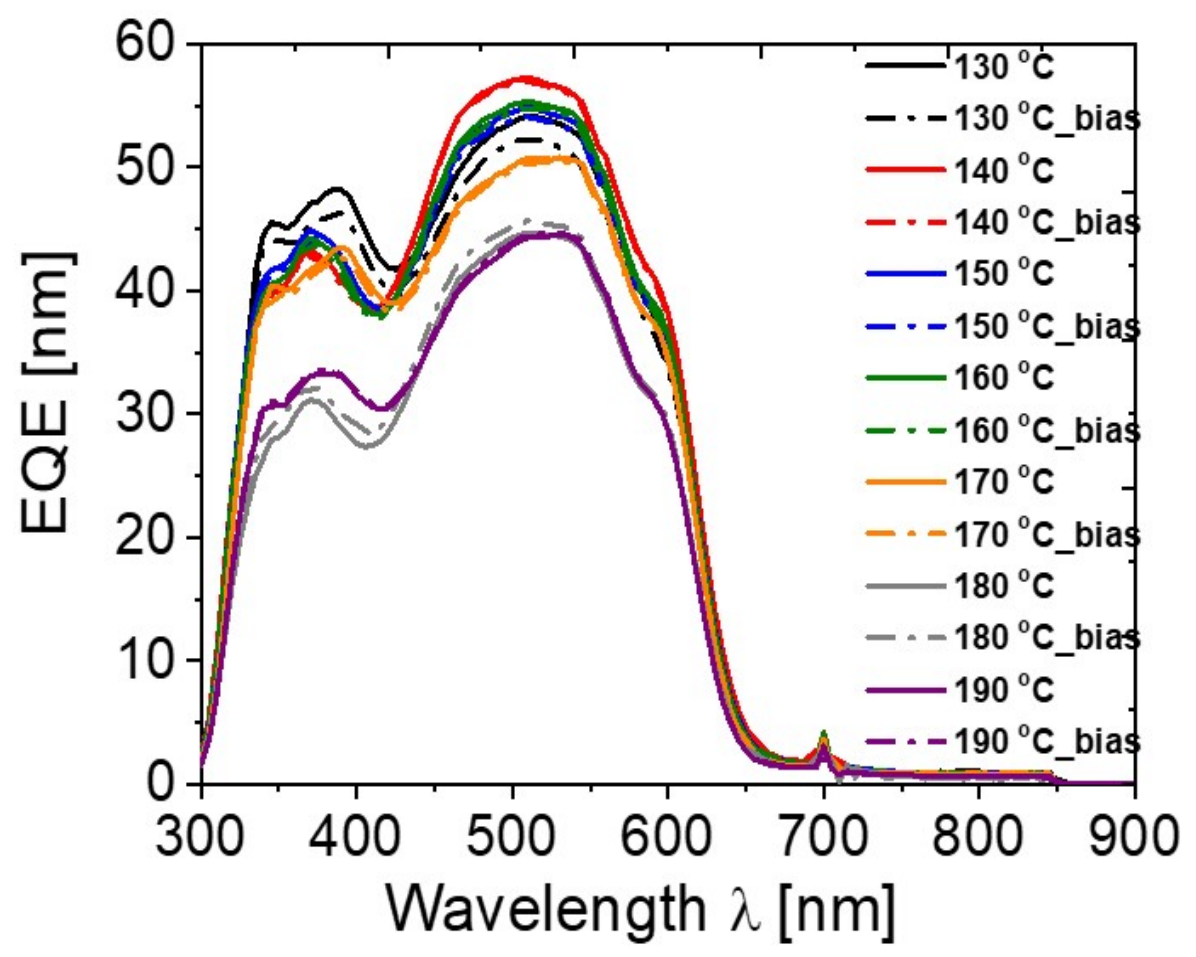

Figure 8. EQE efficiency of the prepared ITO/PEDOT:PSS/P3HT:PC ${ }_{60} \mathrm{BM} / \mathrm{Al}$ OSCs at varied postannealing temperatures.
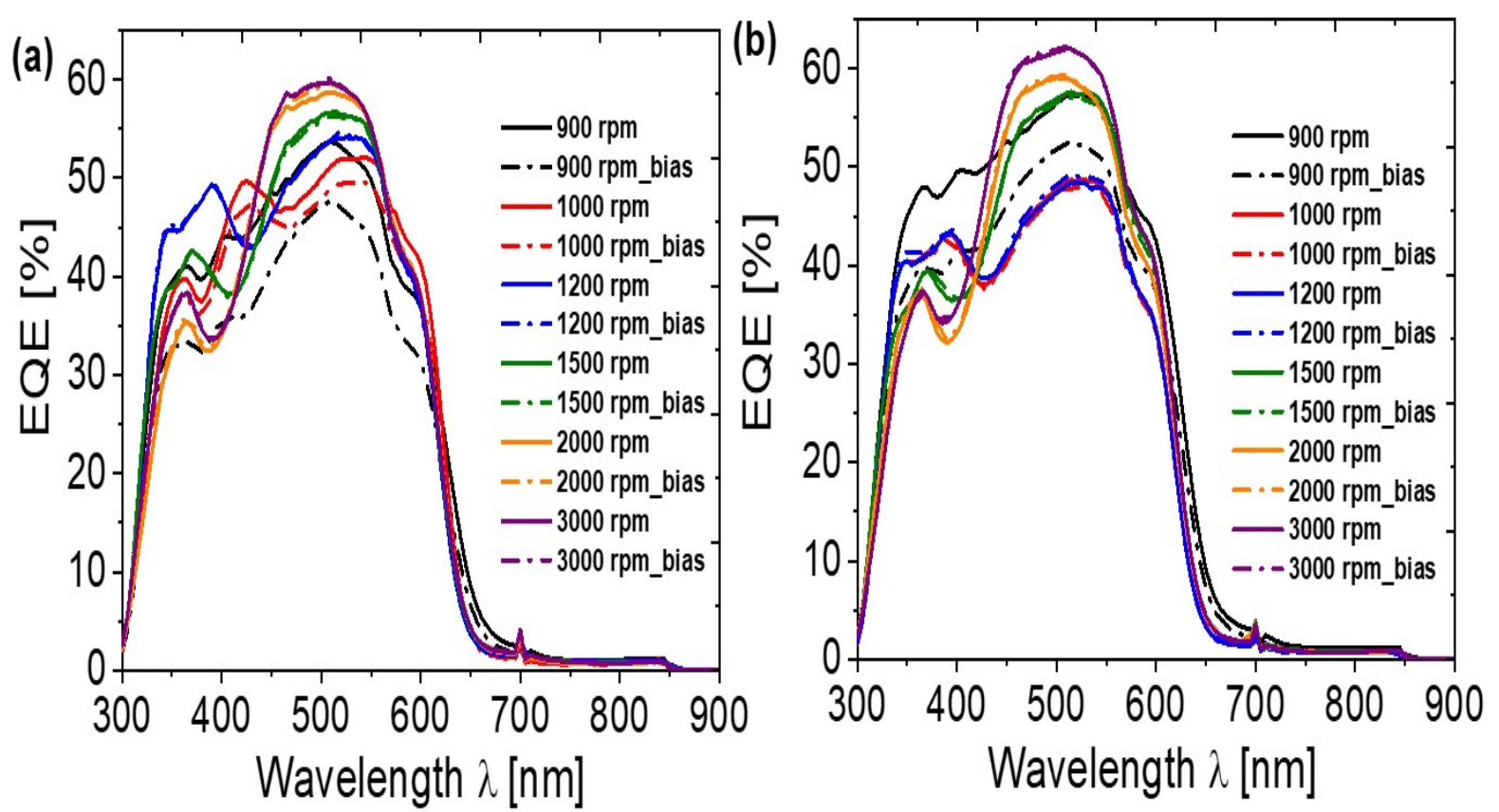

Figure 9. EQE efficiency of the prepared ITO/PEDOT:PSS/P3HT:PC ${ }_{60} \mathrm{BM} /$ cathode OSCs at varied spin coating frequencies utilizing (a) $\mathrm{Al}$ and (b) $\mathrm{Mg}-\mathrm{Al}$ as a cathode.

\section{Conclusions}

ITO-PEDOT:PSS/P3HT:PC ${ }_{60} \mathrm{BM} / \mathrm{Al}$ OSC is designed and optimized. The parameters of fabrication are optimized; post-production annealing temperature, $\mathrm{P} 3 \mathrm{HT}: \mathrm{PC}_{60} \mathrm{BM}$ thickness, and cathode composition (Mg-Al). The HTL, PEDOT:PSS, was prepared under optimized conditions; $3000 \mathrm{rpm}$ for $35 \mathrm{~s}$ and annealing temperature of $178^{\circ} \mathrm{C}$ for $15 \mathrm{~min}$. The active layers, $\mathrm{P} 3 \mathrm{HT}$ and $\mathrm{PC}_{60} \mathrm{BM}$, with a concentration of $2 \mathrm{wt} . \%$ were deposited 
under different spin frequencies, 900 to $3000 \mathrm{rpm}$, using the chlorobenzene as a solvent. The post-production annealing temperature was varied from 130 to $190^{\circ} \mathrm{C}$. For enhancing the electron contact between the active layer and cathode, a thin $\mathrm{Mg}$ metal layer is used with $\mathrm{Al}$ cathode. From our study, the optimum parameters were spin coating at $3000 \mathrm{rpm}$ and an annealing temperature of $160{ }^{\circ} \mathrm{C}$ for $5 \mathrm{~min}$, in the presence of $\mathrm{Mg}$ - $\mathrm{Al}$ as a cathode metal. The optimum J-V parameters values for the prepared solar cell were $J_{S C}=12.01 \mathrm{~mA} / \mathrm{cm}^{2}, V_{O C}=0.660 \mathrm{~V}, F F=59 \%, P C E=4.65 \%$, and $E Q E=61 \%$. Therefore, we have synthesized a complete organic solar cell with acceptable efficiency using easy methods that can be implemented in the industry to provide a renewable energy source for people, particularly in remote areas. Furthermore, the anticipated cost of the synthesized solar cell is about $1 \$ / \mathrm{cm}^{2}$, and we plan to cut the cost even more in the future by using more commercial materials.

Supplementary Materials: The following are available online at https:/ / www.mdpi.com/article/10 .3390 / coatings11070863/s1, Figure S1: the photoluminescence of the P3HT:PCBM under (a) different annealing temperature, (b) different spin speed coating, Figure S2: The integral values of I-V values in light for the effect of (a) annealing temperature, (b) spin speed coating using Al electrode, (c) spin speed coating using Mg-Al electrode, Figure S3: The equivalent circuit model represents $R_{S}$ and $R_{P}$ in (a) dark and (b) light, Figure S4: The $J_{S C}$ and EQE relations under different wavelengths for (a) 130, (b) 140, (c) 150, (d) 160, (e) 170, (f) 180, and (g) $190{ }^{\circ} \mathrm{C}$, Figure S5: The $J_{S C}$ and EQE relations under different wavelengths for (a) 900, (b) 1000, (c) 1200, (d) 1500, (e) 2000, and (f) $3000 \mathrm{rpm}$ for the active layer using Mg-Al cathode, Figure S6: The $J_{S C}$ and EQE relations under different wavelengths for (a) 900, (b) 1000, (c) 1200, (d) 1500, (e) 2000, and (f) $3000 \mathrm{rpm}$ for the active layer using Al cathode, Table S1: the $J_{S C}$ values calculated from EQE values from Figure S4 under different annealing temperatures for the active layer. Table $S 2$. the $J_{S C}$ values calculated from EQE values from Figures S5 and S6 under different spin speed coating for the active layer.

Author Contributions: Data curation, M.S. and M.R.; Formal analysis, M.B.; Funding acquisition, M.S.; Investigation, M.B.; Methodology, A.A. and M.R.; Supervision, M.B. and A.A.; Writing-original draft, M.S. All authors have read and agreed to the published version of the manuscript.

Funding: This research was funded by Deanship of Scientific Research at Islamic University, Madinah, Saudi Arabia. Research project No.: 489.

Institutional Review Board Statement: Not applicable.

Informed Consent Statement: Not applicable.

Data Availability Statement: Not applicable.

Acknowledgments: We would like to thank the deanship of scientific research at the Islamic University of Madinah, Saudi Arabia for the financial support of this work through the program Tamayyuz II of the academic year 2020/2021, research project No.: 489.

Conflicts of Interest: The authors declare no conflict of interest.

\section{References}

1. Meng, L.; Zhang, Y.; Wanm, X.; Li, C.; Zhang, X.; Wang, Y.; Ke, X.; Xiao, Z.; Ding, L.; Xia, R.; et al. Organic and solution-processed tandem solar cells with 17.3\% efficiency. Science 2018, 361, 1094-1098. [CrossRef]

2. Jia, Z.; Qin, S.; Meng, L.; Ma, Q.; Angunawela, I.; Zhang, J.; Li, X.; He, Y.; Lai, W.; Li, N.; et al. High performance tandem organic solar cells via a strongly infrared-absorbing narrow bandgap acceptor. Nat. Commun. 2021, 12, 178. [CrossRef]

3. Jiang, K.; Zhang, J.; Peng, Z.; Lin, F.; Wu, S.; Li, Z.; Chen, Y.; Yan, H.; Ade, H.; Zhu, Z.; et al. Pseudo-bilayer architecture enables high-performance organic solar cells with enhanced exciton diffusion length. Nat. Commun. 2021, 12, 468. [CrossRef]

4. Almohammedi, A.; Khan, M.T.; Benghanem, M.; Aboud, S.W.; Shkir, M.; AlFaify, S. Elucidating the impact of PbI 2 on photophysical and electrical properties of poly (3-hexythiophene). Mater. Sci. Semicond. Process. 2020, 120, 105272. [CrossRef]

5. Ye, L.; Weng, K.; Xu, J.; Du, X.; Chandrabose, S.; Chen, K.; Zhou, J.; Han, G.; Tan, S.; Xie, Z.; et al. Unraveling the influence of non-fullerene acceptor molecular packing on photovoltaic performance of organic solar cells. Nat. Commun. 2020, 11, 6005. [CrossRef]

6. McNeill, C.R.; Halls, J.J.M.; Wilson, R.; Whiting, G.L.; Berkebile, S.; Ramsey, M.G.; Friend, R.H.; Greenham, N.C. Efficient polythiophene/polyfluorene copolymer. bulk heterojunction photovoltaic devices: Device physics and annealing effects. Adv. Funct. Mater. 2008, 18, 182309-182321. [CrossRef] 
7. Savenije, T.J.; Kroeze, J.E.; Yang, X.; Loos, J. The formation of crystalline P3HT fibrils upon annealing of a PCBM:P3HT bulk heterojunction. Thin Solid Film 2006, 511-512, 2-6. [CrossRef]

8. Abada, Z.; Mellit, A.; Benghanem, M. Influence of blend composition and annealing temperature on optical properties of organic photovoltaic cell based on P3HT: PCBM interpenetrating blend. Int. J. Green Energy 2020, 17, 101-113. [CrossRef]

9. Zhao, G.; He, Y.; Li, Y. 6.5\% Efficiency of polymer solar cells based on poly(3-hexylthiophene) and indene-C60 bisadduct by device optimization. Adv. Mater. 2010, 22, 4355-4358. [CrossRef]

10. Chen, D.; Nakahara, A.; Wei, D.; Nordlund, D.; Russell, T.P. P3HT/PCBM bulk heterojunction organic photovoltaics: Correlating efficiency and morphology. Nano Lett. 2011, 11, 561-567. [CrossRef]

11. Green, M.A.; Emery, K.; Hishikawa, Y.; Warta, W.; Dunlop, E.D. Solar cell efficiency tables (version 46). Prog. Photovolt. 2015, 23, 1-7. [CrossRef]

12. Reyes-Reyes, M.; Kim, K.; Carroll, D.L. High-efficiency photovoltaic devices based on annealed poly(3-hexylthiophene) and 1-(3-methoxycarbonyl)-propyl-1-phenyl-(6,6)C61 blends. Appl. Phys. Lett. 2005, 87, 083506. [CrossRef]

13. Li, G.; Shrotriya, V.; Yao, Y.; Yang, Y. Investigation of annealing effects and film thickness dependence of polymer solar cells based on poly(3-hexylthiophene). J. Appl. Phys. 2005, 98, 043704. [CrossRef]

14. Erb, T.; Zhoukhavets, U.; Gobsch, G.; Raleva, S.; Steuhn, B.; Schilinsky, P.; Waldauf, C.; Brabec, C.J. Correlation between structural and optical properties of composite polymer/fullerene films for organic solar cells. Adv. Funct. Mater. 2005, 15, 1193-1196. [CrossRef]

15. Madogni, V.I.; Kounouhéwa, B.; Akpo, A.; Agbomahéna, M.; Hounkpatin, S.A.; Awanou, C.N. Comparison of degradation mechanisms in organic photovoltaic devices upon exposure to a temperate and a subequatorial climate. Chem. Phys. Lett. 2015, 640, 201-214. [CrossRef]

16. Jørgensen, M.; Norrman, K.; Gevorgyan, S.A.; Tromholt, T.; Andreasen, B.; Krebs, F.C. Stability of Polymer Solar Cells. Adv. Mater. 2012, 24, 580-612. [CrossRef] [PubMed]

17. Manceau, M.; Rivaton, A.; Gardette, J.L.; Guillerez, S.; Lemaitre, N. Light induced degradation of the P3HT-based solar cells active layer. Sol. Energy Mater. Sol. Cells 2011, 95, 1315-1325. [CrossRef]

18. Glen, T.S.; Scarratt, N.W.; Yi, H.; Iraqi, A.; Wang, T.; Kingsley, J.; Buckley, A.R.; Lidzey, D.G.; Donald, A.M. Grain size dependence of degradation of aluminum/calcium cathodes in organic solar cells following exposure to humid air. Sol. Energy Mater. Sol. Cells 2015, 140, 25-32. [CrossRef]

19. Turkovic, V.; Engmann, S.; Egbe, D.A.M.; Himmerlich, M.; Krischok, S.; Gobsch, G.; Hoppe, H. Multiple stress degradation analysis of the active layer in organic photovoltaics. Sol. Energy Mater. Sol. Cells 2014, 120, 654-668. [CrossRef]

20. Hou, X.; Wang, Y.; Lee, H.K.H.; Datt, R.; Miano, N.U.; Yan, D.; Li, M.; Zhu, F.; Hou, B.; Tsoi, W.C.; et al. Indoor application of emerging photovoltaics-Progress, challenges and perspectives. J. Mater. Chem. A 2020, 8, 21503-21525. [CrossRef]

21. Lin, C.; Lin, E.Y.; Tsai, F.Y. Enhanced thermal stability and efficiency of polymer bulk-heterojunction solar cells by low-temperature drying of the active layer. Adv. Funct. Mater. 2010, 20, 834-839. [CrossRef]

22. Reese, M.O.; Nardes, A.M.; Rupert, B.L.; Larsen, R.E.; Olson, D.C.; Lloyd, M.T.; Shaheen, S.E.; Ginley, D.S.; Rumbles, G.; Kopidakis, N. Photoinduced degradation of polymer and polymer-fullerene active layers: Experiment and theory. Adv. Funct. Mater. 2010, 20, 3476-3483. [CrossRef]

23. Jørgensen, M.; Norrman, K.; Krebs, F.C. Stability/degradation of polymer solar cells. Sol. Energy Mater. Sol. Cells 2008, 92, 686-714. [CrossRef]

24. Mihailetchi, V.D.; Koster, L.J.A.; Blom, P.W.M.; Melzer, C.; de Boer, B.; van Duren, J.K.J.; Janssen, R.A.J. Compositional dependence of the performance of poly(p-phenylene vinylene): Methanofullerene bulk-heterojunction solar cells. Adv. Funct. Mater. 2005, 15, 795-801. [CrossRef]

25. Padinger, F.; Rittberger, R.S.; Sariciftci, N.S. Effects of postproduction treatment on plastic solar cells. Adv. Funct. Mater. 2003, 13, 85-88. [CrossRef]

26. Schilinsky, P.; Waldauf, C.; Brabec, C.J. Recombination and loss analysis in polythiophene based bulk heterojunction photodetectors. Appl. Phys. Lett. 2002, 81, 3885-3887. [CrossRef]

27. Huang, J.; Li, G.; Yang, Y. Influence of composition and heat-treatment on the charge transport properties of poly(3hexylthiophene) and [6,6]-phenyl C61-butyric acid methyl ester blends. Appl. Phys. Lett. 2005, 87, 112105. [CrossRef]

28. Li, G.; Shrotriya, V.; Huang, J.; Yao, Y.; Moriarty, T.; Emery, K.; Yang, Y. High-efficiency solution processable polymer photovoltaic cells by self-organization of polymer blends. Nat. Mater. 2005, 4, 864-868. [CrossRef]

29. Supriyanto, A.; Mustaqim, A.; Agustin, M.; Ramelan, A.H.; Rosa, E.S.; Nurosyid, F. Fabrication of organic solar cells with design blend P3HT:PCBM variation of mass ratio. Ser. Mater. Sci. Eng. 2016, 107, 012050.

30. Chi, D.; Qu, S.; Wang, Z.; Wang, J. High efficiency P3HT:PCBM solar cells with an inserted PCBM layer. J. Mater. Chem. C 2014, 2, 4383. [CrossRef]

31. Chang, S.C.; Hsiao, Y.J.; Li, T.S. P3HT:PCBM incorporated with silicon nanoparticles as photoactive layer in efficient organic photovoltaic devices. L Nanomater. 2013, 2013, 1-4. [CrossRef]

32. Khairulaman, F.L.; Yap, C.C.; Jumali, M.H. Improved performance of inverted type organic solar cell using copper iodide-doped P3HT:PCBM as active layer for low light application. Mater. Lett. 2021, 283, 128827. [CrossRef] 
33. Yaacobi-Gross, N.; Treat, N.D.; Pattanasattayavong, P.; Faber, H.; Perumal, A.K.; Stingelin, N.; Bradley, D.D.C.; Stavrinou, P.N. High-efficiency organic photovoltaic cells based on the solution-processable hole transporting interlayer copper thiocyanate (CuSCN) as a replacement for PEDOT:PSS. Adv. Energy Mater. 2015, 5, 1401529. [CrossRef]

34. Alam, S.; Meitzner, R.; Kaestner, C.; Ulbricht, C.; Hoeppener, S.; Egbe, D.A.M.; Schubert, U.S.; Hoppe, H. Controlling donor crystallinity and phase separation in bulk heterojunction solar cells by the introduction of orthogonal solvent additives. MRS Adv. 2018, 3, 1891-1900. [CrossRef]

35. Yu, R.; Yao, H.; Cui, Y.; Hong, L.; He, C.; Hou, J. Improved charge transport and reduced nonradiative energy loss enable over 16\% efficiency in ternary polymer solar cells. Adv. Mater. 2019, 31, 1902302. [CrossRef]

36. Liu, Y.; Zhang, J.; Zhou, G.; Liu, F.; Zhu, X.; Zhang, F. Electric field facilitating hole transfer in non-fullerene organic solar Cells with a negative HOMO offset. J. Phys. Chem. C 2020, 124, 15132-15139. [CrossRef]

37. Saeed, M.A.; Kim, S.H.; Kim, H.; Liang, J.; Woo, H.Y.; Kim, T.G.; Yan, H.; Shim, J.W. Indoor organic photovoltaics: Optimal cell design principles with synergistic parasitic resistance and optical modulation effect. Adv. Energy Mater. 2021, 2003103. [CrossRef]

38. Goo, J.S.; Lee, J.H.; Shin, S.C.; Park, J.S.; Shim, J.W. Undoped ZnO electrodes for low-cost indoor organic photovoltaics. Mater. Chem. A 2018, 6, 23464. [CrossRef] 